\title{
King Talal reservoir case study; water quality, treated wastewater use for irrigation and its risk assessment, irrigation type and crop selection
}

\begin{abstract}
According to the World Health Organization (WHO), Jordan is one of the poorest countries in the world in terms of water availability. The amount of water available per capita is 14 per cent less than the world's water poverty line. Irrigated agriculture is currently the largest consumer (Gunn, 2009). King Talal Reservoir is considered to be the largest supplier for the agricultural sector in the Jordan Valley region. The area planted annually in the Jordan Valley is about 31,600 hectares mainly taken up by irrigated vegetables and citrus orchards. The irrigation water resources for this area are the King Talal Dam, the King Abdullah Canal and runoff from the Zarqa River (Hasan, et al. 2000)

This paper aims to study the quality of the King Talal Dam water over a period of four years as most of its water content is a treated wastewater which is coming from Khirbet Al Samra Water Treatment Plant, and Jerash and Baq'a Water Treatment Plants, and to determine the safe use of this water in agriculture and how to choose the crops for this type of water, also to determine if the Jordan Valley farmer's need to change the type of their crops and what is the most suitable water irrigation type depending on water quality, and finally a qualitative risk assessment has been done for using treated wastewater in un-restricted agriculture.

This study shows that the localized irrigation system (drip, trickle or splitter) is the most suitable method of irrigation in the Jordan Valley. The high sodium and chloride concentrations prohibit the use of sensitive crops to salinity in Jordan valley's agriculture (FAO Guidelines, 1989), depending on the risk assessment the existing regulations for using treated wastewater in agriculture should be reviewed and issuing a new guide lines for treated wastewater use in irrigation.
\end{abstract}

Keywords: King Talal Dam, water quality, irrigation type, crop selection, qualitative risk assessment for using treated wastewater, crop selection in Jordan valley
Volume 4 Issue 2 - 2019

\section{Tharwa Qotaish}

Royal Scientific Society, Jordan

Correspondence: Qotaish Tharwa, Royal Scientific Society/ Knowledge Cluster/Water and Environment Center. P.O. Box |438 Amman I| 94 I Jordan, Email tharwh.qutaish@rss.jo

Received: December 10, 2018 | Published: March 13,2019

\section{Introduction}

Jordan is located in an arid to semi arid region where around $90 \%$ of the country's land receives an average precipitation of less than $100 \mathrm{~mm} /$ year while only $3 \%$ of the land receives an average annual precipitation of $300 \mathrm{~mm}$ or more. Jordan is considered to be one of the 10 poorest countries worldwide in water resources, and has a population growth rate of about $2.9 \%$ (1998-2002), the 9th highest in the world. The available renewable water resources have drastically dropped to an annual per capita share of $160 \mathrm{~m}^{3}$ in recent years, compared to $3600 \mathrm{~m}^{3} / \mathrm{cap} / \mathrm{a}$ in $1946 .{ }^{1}$ Factors prompting such a decrease include, aside from the most prominent one of rapid population growth, sudden influx of refugees due to political instability in the region and an ever increasing demand on limited fresh water sources. ${ }^{2}$ Even though dams are expensive to construct, they are among the major solutions the country relies on to secure its needs of water. Jordan has 10 major dams that supply water for both irrigation and human consumption. These dams currently hold only 40 per cent of their total storage capacity. Nowadays, irrigated agriculture is the largest consumer constituting around $64 \%$ of the overall uses compared to only $36 \%$ for municipal, industrial and tourism (MIT) purposes.

Thus; Jordan faces water poverty and the management of water resources is a primary duty that the successive government of Jordan has lately been paying attention to.
Irrigation in Jordan occurs mainly in three distinct areas: The Jordan Rift Valley, the North-eastern Desert and Azraq region, and the Southern Desert in the Disi and Mudawwara areas. The main source for irrigation water in the Jordan Rift Valley (JRV) is the Yarmouk River and the side wadis, in addition to treated wastewater. ${ }^{4}$ The Water Strategy policy states that "Wastewater shall not be managed as 'waste'; it shall be collected and treated to standards that allow its use in unrestricted agriculture and other non domestic purposes including ground water recharge". ${ }^{5}$ The construction of the King Talal Dam on the Zarqa River helped in formulating that policy. The reservoir was a perfect place for blending the wastewater (King Talal Dam receives the majority of its water from Khirbet Al Samra Water Treatment Plant, the other water sources are (Jerash and Baq'a plants) with the impounded flood water and for regulating the flow of the Zarqa River. ${ }^{6}$

Few studies have quantified the aggregate contribution of wastewater to food supply. In Pakistan, about 26 per cent of national vegetable production is irrigated with wastewater, ${ }^{7}$ while in Hanoi, Vietnam, which is much wetter than Pakistan, about 80 per cent of vegetable production is from urban and peri-urban areas irrigated with diluted wastewater. ${ }^{8}$ Across major cities in West Africa, between 50 and 90 per cent of vegetables consumed by urban dwellers are produced within or close to the city where much of the water used is polluted.9 Also, in Lebanon and Palestine most of the wastewater collected from sewered localities is discharged into nearby rivers, wadis, and the sea, and on an open land from where it infiltrates the 
ground with little or no treatment. ${ }^{10}$ In Turkey, an enormous amount of domestic wastewater is discharged into rivers and used for irrigation because of insufficient sewerage facilities and lack of satisfactory treatment. ${ }^{11}$

\section{Methodology}

Water samples for physical, chemical and microbiological analyses were taken every two months at KTR outlet for four years (20052008), ${ }^{12}$ the tests were conducted in accordance with the "Standard Method for the Examination of Water and Wastewater, Online". And finally, the results were assessed with reference to FAO (Food and Agriculture Organization) guidelines. A committee from different governmental institutions experts Led by GTZ develop a qualitative risk monitoring and management system for the safe use of treated wastewater depending on WHO Guidelines on Wastewater Use in Agriculture/2006 in order to protect health and environment; mainly in two phases:

Phase one: reviewing the mandate of each relevant institutions as stated in the official gazette. Accordingly, responsibilities were delineated and existing monitoring programs were determined.

Phase two: developing a risk matrix upstream and downstream KTR, which went through different steps:

\section{Risk characterization}

A. identify affected targets along the pilot area
B. identify hazard sources and types exist along the pilot area

2. Risk assessment: rate the identified risks and define their health and environmental consequences (A semi-quantitative risk matrix approach was used).

3. Identify existing control measures and monitoring programs and reassessing risks accordingly

4. Propose a risk management plan that control and mitigate to a large extent the negative impact of the identified risks.

\section{Results and discussion}

The King Talal reservoir (KTR) is a large dam in the hills of northern Jordan, across the Zarqa River. The King Talal reservoir was started in 1971, with the original construction being completed in 1977. In 1984, to meet the country's increased water demands, work to raise the dam further was begun, a project that was completed in 1988. The reclaimed water is mixed with surface run-off from wadis before it is temporarily stored in the country's largest reservoir (which has a storage capacity of 75 million cubic meter). The detention time of the water in the reservoir which used to be ten months has been reduced to a few months with the increase of the wastewater flow. About $20 \mathrm{~km}$ downstream from the KTR outlet, some Jordan Valley farm's divert part of the KTR water directly to their fields. The rest of the reclaimed water is finally released into the king Abdullah Canal which brings fresh water in the north to the Jordan valley (Figure 1) (Table 1).

Table I Physical Chemical and Biological analysis through 2005-2008

\begin{tabular}{|c|c|c|c|c|c|c|c|c|}
\hline \multicolumn{4}{|c|}{ Averages* } & \multicolumn{3}{|c|}{ FAO Guidelines for Irrigation Water Quality } & \multirow{2}{*}{ Unit } & \multirow{2}{*}{ Parameter } \\
\hline 2008 & 2007 & 2006 & 2005 & Sever & Slight moderate & None & & \\
\hline 7.69 & 7.8 & 7.68 & 7.87 & & $6.5-8.4$ & & SU & $\mathrm{pH}$ \\
\hline 2253 & 2295 & 2481 & 2320 & $>3000$ & $700-3000$ & $<700$ & $\mu \mathrm{S} / \mathrm{cm}$ & EC \\
\hline 1319 & 1275 & 1427 & 1263 & $>2000$ & $450-2000$ & $<450$ & $\mathrm{mg} / \mathrm{L}$ & TDS \\
\hline 5 & 21 & 15 & 14 & $>100$ & $50-100$ & $<50$ & $\mathrm{mg} / \mathrm{L}$ & TSS \\
\hline 263 & 243 & 240 & 199 & $0-70$ & & & $\mathrm{mg} / \mathrm{L}$ & $\mathrm{Na}(\mathrm{I})$ \\
\hline 50 & 45 & 59 & 46 & ---- & & & $\mathrm{mg} / \mathrm{L}$ & $\mathrm{Mg}$ \\
\hline 121 & 130 & 135 & 143 & ----- & & & $\mathrm{mg} / \mathrm{L}$ & $\mathrm{Ca}$ \\
\hline 5.07 & 4.67 & 4.33 & 3.71 & $3-9$ & & & --- & SAR \\
\hline 401 & 402 & 414 & 402 & $142-325$ & & & $\mathrm{mg} / \mathrm{L}$ & $\mathrm{Cl}(2)$ \\
\hline 342 & 490 & 591 & 538 & $>535$ & $95-535$ & $<95$ & $\mathrm{mg} / \mathrm{L}$ & $\mathrm{HCO} 3$ \\
\hline 0.046 & 0.06 & 0.13 & 0.07 & 0.2 & & & $\mathrm{mg} / \mathrm{L}$ & $M n$ \\
\hline 0.05 & $<0.12$ & $<0.12$ & 0.2 & 5 & & & $\mathrm{mg} / \mathrm{L}$ & $\mathrm{Fe}$ \\
\hline 0.6 & 0.66 & 0.41 & 1.67 & $>3$ & $0.7-3$ & $<0.7$ & $\mathrm{mg} / \mathrm{L}$ & B \\
\hline $1.18 E+04$ & $1.29 E+04$ & $2.13 E+03$ & $5.04 \mathrm{E}+02$ & ----- & & & $\mathrm{MPN} / 100 \mathrm{~mL}$ & $\mathrm{TCC}$ \\
\hline $1.07 E+02$ & $9.59 E+02$ & $1.33 E+02$ & $9.40 \mathrm{E}+0 \mathrm{I}$ & $\leq 1000 * *$ & & & MPN/I00mL & TFCC \\
\hline $4.52 \mathrm{E}+0 \mathrm{I}$ & $9 .|7 E+0|$ & $1.10 \mathrm{E}+02$ & ----- & $\leq 1000 * *$ & & & MPN/I00mL & E.coli \\
\hline $\begin{array}{l}\text { Not } \\
\text { Detected }\end{array}$ & $\begin{array}{l}\text { Not } \\
\text { Detected }\end{array}$ & $\begin{array}{l}\text { Not } \\
\text { Detected }\end{array}$ & $\begin{array}{l}\text { Not } \\
\text { Detected }\end{array}$ & $\leq I^{* *}$ & & & Count/ $5.0 \mathrm{~L}$ & $\begin{array}{l}\text { Intestinal Pathogenic } \\
\text { Nematode Eggs }\end{array}$ \\
\hline
\end{tabular}

(I): The values are applied for sprinkler irrigation

(2): The values are applied for surface irrigation, for sprinkler irrigation the values are: less than $105 \mathrm{mg} / \mathrm{L}$ for no restriction, and more than 105 for a slightmoderate degree of restriction.

*:Arithmetic mean except for (TCC,TTCC and E.coli) geometric mean 


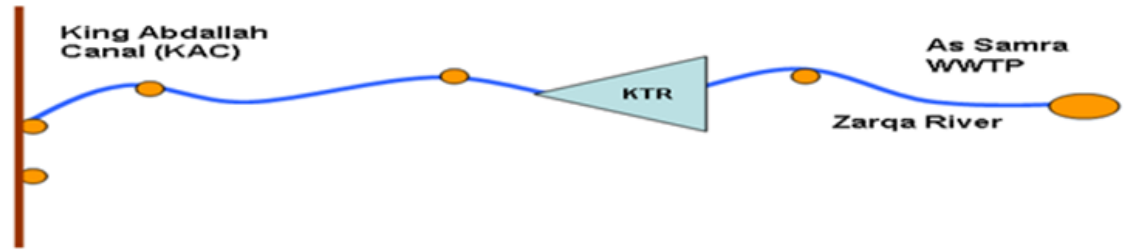

Figure I Flow of treated wastewater from the source (WWTP) into Zarqa River then into KTR until it ends into King Abdullah Canal.

Water quality refers to the characteristics of a water supply that will affect its suitability for a specific use. Quality is determined by certain physical, chemical and biological characteristics. It is through the study of certain properties of water that we see how it fits an intended use, in this case being irrigation of agricultural crops.

$\mathrm{pH}$ is a measure of the acidity or basicity of a water. In a water analysis, $\mathrm{pH}$ is mainly measured to detect abnormal water. Irrigation water with a $\mathrm{pH}$ outside the normal range (6.5 to 8.4) may cause a nutritional imbalance or may contain a toxic ion.

According to the FAO guidelines, the $\mathrm{pH}$ values of the studied samples impose a slight to moderate degree of restriction on the use of water for irrigation.

TDS (soil salinity): The primary objective of irrigation is to provide a crop with sufficient amounts of water. When crop uses water, the upper root zone becomes depleted and water moves toward the deeper parts- which are usually more salty- as the time interval between irrigations is extended.

The crop does not respond to extremes of high or low salinity in the rooting depth; it takes water from wherever it is most readily available.

Salinity refers to the dissolved cations and anions of soils and water. Salt is a natural element of soils and water; but if present in excessive amounts it causes problems.

Excessive salinity prevents the crop from extracting sufficient water from the salty soil solution and hence the plant's growth is slowed and a yield loss will occur.

Different plants respond differently to salinity. Some crops are better able to make osmotic adjustments allowing them to extract more water from a saline soil and thus these crops can produce acceptable yields at much greater soil salinity than others. The ability to adjust salinity is quite useful. In certain areas where the soil salinity cannot be controlled to suit the crop being grown, a more tolerant crop can be selected instead.

Salinity is reflected in the TDS value. Because the rainfall amount in 2006/2007 was greater than that in 2005/2006, the TDS value in 2007 was lower due to the dilution of salts by rain water. (The rainfall season in Jordan lasts from the beginning of December to the end of May).

It is also noticed that the TDS value slightly increased in 2008 and this is because the rainfall amount in 2007/2008 was lower than that in $2006 / 2007$. In other words, less precipitation means salts will be more concentrated (Rainfall amounts obtained from Jordan Meteorological Department).

The average TDS values impose a slight to moderate degree of restriction on the use of water according to the FAO guidelines. This means that the dam's water is to be used for the irrigation of certain types of crops only. Other types of crops will not tolerate the salinity of the water and therefore should not be irrigated with it.

Chloride and sodium: Chloride is not absorbed or held back by soils, therefore it moves readily with the soil-water. It is taken up by the crop after which it moves in the transpiration stream, and accumulates in the leaves. If the chloride concentration in the leaves exceeds the tolerance of the crop, injury symptoms develop such as leaf burn or drying of lea tissue.

Relatively high sodium concentrations in the water cause sodium toxicity which is not as easily diagnosed as chloride toxicity. Sodium toxicity is often modified or reduced if sufficient calcium is available in the soil.

The results in the above tables show that the concentrations of sodium and chloride impose a severe degree of restriction on the use of surface and sprinkler irrigation.

Infiltration: It is the entry of water into the soil. The infiltration rate generally increases with increasing salinity and decreases with either decreasing salinity or increasing sodium content relative to calcium and magnesium - the sodium absorption ratio (SAR).

An infiltration problem related to water quality is caused by excessive sodium in irrigation water, which promotes soil dispersion, structural breakdown and plugging of the surface pores, but only if sodium exceeds calcium by more than a ratio of about $3: 1$. Since the $\mathrm{Na}$ :Ca ratio in the collected samples is less than $3: 1$, the dam's water will not cause infiltration problems.

SAR: The sodium absorption ratio (SAR), currently referred to as $\mathrm{RNa}$, encompasses the infiltration problems due to an excess of sodium compared to calcium and magnesium.

Sodium remains soluble and in equilibrium with exchangeable soil sodium at all times. On the other hand, calcium does not remain completely soluble or in constant supply but is constantly changing until an equilibrium is established.

The average SAR values in the last 4 years comply with the FAO guidelines.

$\mathbf{N O}_{3}$ : Nitrogen is a plant nutrient necessary for stimulating plant growth. The usual sources are natural soil nitrogen or added fertilizers. Nitrogen in irrigation water pretty much has the same effect as soil-applied fertilizer nitrogen and an excess will cause problems. Excessive nitrogen quantities over-stimulate growth, delay maturity or cause the crop to have poor quality. High nitrogen levels may be beneficial during early growth stages but may cause yield losses during the later flowering and fruiting stages. Therefore, later in the growing season, the nitrogen applied to the crop must be significantly reduced.

Less than $5 \mathrm{mg} / 1$ nitrogen has little effect, but may stimulate growth of algae and aquatic plants in lakes, streams, canals and 
drainage ditches and thereby increases maintenance costs for clearing vegetation from canals and drainage channels.

It is noticed that the concentration of $\mathrm{NO}_{3}$ in 2008 is higher than that in previous years. This is explained by the fact that the Khirbet Al Samra Plant, which is the major dam-water source, was converted in that same year to a mechanical system that caused nitrification. The concentration of $\mathrm{NO}_{3}$ in the samples collected from the plant's outlet in 2008 was higher than previous.

Farmers should be made aware of the increasing concentration of $\mathrm{NO}_{3}$ in order to cut down on the use of fertilizers to prevent yield loss.

Boron: It is an essential element for plant growth. However, it is needed in relatively small amounts and if present in greater amounts than needed, it becomes toxic. In both 2007 and 2008, Boron imposed no degree of restriction on the use of water.

Trace elements (Fe, Mn): Trace elements occur in almost all water supplies but at very low concentrations. Many of them- such as Fe, $\mathrm{Mn}$, Mo and $\mathrm{Zn}$ - are not toxic in small quantities and are essential for plant growth. However, excessive quantities will cause both undesirable accumulations in plant tissue and growth reduction. The concentrations of $\mathrm{Fe}$ and $\mathrm{Mn}$ in the past 4 years comply with the FAO guidelines.

E coli: From 2006-2008, there has been a decrease in the concentration of $E$ coli, which are a biological indicator, because the quality of water coming from Khirbet Al Samra Plant had improved.

Intestinal pathogenic nematode eggs: A positive aspect of the dam is that throughout the 4 years of observation, no Intestinal Pathogenic Nematode Eggs were detected.

The results above determine what method of irrigation is most suitable, and what crops to select for growing in the Jordan Valley.

\section{Methods of irrigation}

The method of irrigation directly affects both the efficiency of water use and the way in which salts are accumulated. The water quality of the KTR shows that the most suitable method of irrigation is the localized irrigation system (drip, trickle or splitter).

With good quality water, yields with localized (drip) irrigation should be equal to or better than other methods under comparable conditions with higher salinity $(\mathrm{ECw}>1.0 \mathrm{ds} / \mathrm{m})$.

Yields are often better due to continuous high moisture content maintained by daily replenishment of the water used by the crops.

In a drip irrigation system, water must pass through very small openings or emitters that often become clogged. Installation of proper equipment to prevent clogging at the beginning is usually less expensive than trying to correct the problem afterwards.

The potential for clogging problems is dictated by the TSS value and by biological indicators. Since the TSS values in the results table are less than $50 \mathrm{mg} / 1$, and the bacterial population is less than $10,000 /$ $\mathrm{ml}$, there is no risk of clogging; or at least not any time soon. ${ }^{13}$

\section{Crop selection}

Selecting a more tolerant crop offers a very practical solution to toxicity problems. There are degrees of sensitivity to sodium and chloride just as there are degrees of sensitivity to salinity. The selection of tolerant root stocks or cultivars is another method of changing the crop to cope with existing conditions.

\section{Risk assessment}

In the old guidelines, WHO 1989 recommended the implementation of rather stringent approach depending mainly on single barrier approach. This approach requires treating wastewater at a state-ofthe-art treatment plant to render treated water of an acceptable quality for reuse purposes. In $2006 \mathrm{WHO}-\mathrm{FAO}-\mathrm{UNEP}$ issued new guidelines for the use of treated wastewater. The new guidelines encourage the use of multiple barriers approach which is more flexible and less stringent. This approach combines treatment and post-treatment barriers compared to the old approach that relies solely on treatment plant as the only reliable control measure. The rationale for this flexibility is due to the understanding of socioeconomic status of developing countries and the dire need to exploit treated wastewater in dry countries. However, it is by no means acceptable to use partially treated wastewater in a way that compromises the health of people. For a rationale adaptation and implementation of the new guidelines, a risk management system shall be in place in areas where treated wastewater is used for irrigation.

Risk Management System as defined by the new WHO guidelines is the systematic evaluation of the wastewater use system, the identification of hazards and hazardous events, the assessment of risks and the development and implementation of preventative strategies to manage the risks. The development of risk management system should consider the following:

a. Boundary identification for the entire system

b. Boundaries identification for each involved stakeholder

c. Risk identification: list all risks associated with the use of reclaimed water from the point of source until consumer table (biological, chemical, physical)

d. Risk assessment for all risks in terms of frequency and consequences (human health impact, soil degradation, ground water pollution) to end up with risk quantification which in turn allows risk prioritization

e. Appraisal of existing monitoring programs to assess their efficiency, and if there is a need to further develop new programs(i.e. soil, water and ground water monitoring programs)

f. Assessment of the existing risk management measures (hazard barriers like treatment plant, drip irrigation, natural die-off and hygiene practices etc.)

g. Propose further risk management measures to curb risks occurrence.

The committee from different governmental institutions Led by GTZ; attended 9 meetings, the first meeting was on July $9^{\text {th }}, 2009$ and the last one was on January $5^{\text {th }}, 2010$. Throughout these meeting, a risk monitoring and management plan for the safe use of reclaimed water upstream and downstream KTR was developed through the following tasks:

1) Review the mandate of each relevant institution and identify responsibilities

2) Undertake a hazard assessment and a risk characterization for the pilot area

3) Assess the existing control measures and propose new ones where needed 
4) Assess the existing monitoring system, Identify overlaps and gaps, and propose new monitoring system where needed

5) Develop a risk management plan

6) Document the system.

It has been found that the existing regulations for using treated wastewater in agriculture should be reviewed and issuing a new guide lines for treated wastewater use in irrigation; as the Jordan regulations for using this type of water depend on a very restricted regulations JS $(893 / 2006))^{14,15}$

\section{Conclusion}

Re-using wastewater is advantageous because it can remove a potential cause of surface or ground water pollution and, at the same time, release higher quality water for other uses. It is therefore recommended to carry out extensive environmental research on a yearly basis to test for all parameters of water. By continuous monitoring and testing, it can be known whether the quality of water has remained the same, improved or exacerbated.

This study shows that the localized irrigation system (drip, trickle or splitter) is the most suitable method of irrigation in the Jordan Valley. The high sodium and chloride concentrations prohibit the use of surface and sprinkler irrigation, selecting a more tolerant crop offers a very practical solution to toxicity problems.

And, because wastewater contains impurities, careful consideration must be given to the long-term effects on soils by actually testing the soils for salinity, nutrient and trace element content.

Finally depending on the risk assessment new irrigation water quality guidelines should be issued.

\section{Acknowledgments}

None.

\section{Conflicts of interest}

Authors declare that there is no conflict of interest.

\section{References}

1. Tarawneh Zeyad S, Hadadin Nidal A, Bdour Ahmad N. Policies to enhance water sector in Jordan. American Journal of Applied Sciences 2008;5(6):698-704.
2. Wardam Batir. National Capacity Self Assessment for Global Environmental Management (NCSA)-Jordan. Ministry of Environment; 2006.

3. Jordan Times. Major Dams now ready to store winter rain. 2006.

4. Duqqah M, Mazahreh S, Shatanawi M, et al. Water Use Efficiency and Water Productivity in Jordan. Faculty of Agriculture, University of Jordan.

5. Jordan Ministry of Water and Irrigation. Jordan's wastewater policy; 1997.

6. Namrouqa Hana. Jordan Valley Farmers to receive less than half of water needs next year. Jordan Times; 2008.

7. Ensink J, Mahmood T, van der Hoek W, et al. A nation-wide assessment of wastewater use in Pakistan: an obscure activity or a vitally important one? Water Policy. 2004;6(3):197-206.

8. Lai T. Perspectives of peri-urban vegetable production in Hanoi. Background paper prepared for the Action Planning Workshop of the CGIAR Strategic Initiative for Urban and peri-urban Agriculture (SIUPA), Hanoi, 6-9 June, Lima, Peru: International Potato Center (CIP); 2002.

9. Drechsel P, Graefe S, Sonou M, et al. Informal irrigation in urban West Africa: an overview. Sri Lanka: International Water Management Institute; 2006.

10. Post J. Wastewater treatment and reuse in eastern Mediterranean region. Water 2. 2006:36-41.

11. Juanico M, Salgot M. Northern Mediterranean world. In: Jiménez B, Asano T, editors. Water Reuse: An International Survey of Current Practice, Issues and Needs. London: IWA Publishing; 2008. 648 p.

12. National Project for Water Quality Monitoring in Jordan, 2005-2008. Jordan: Royal Scientific Society.

13. Westcot DW, Ayres RS. Water Quality for Agriculture. Food and Agriculture Organization of the United Nations; 1989.

14. Gunn Neil. Water Scarcity in Jordan is damaging its Economy. 2009

15. Hassan Mahmoud, Hussein Iyad, Wahshah Suhail. Applying a decision support system to optimize the King Abdallah Canal at the Jordan Valley. Journal of Environmental Hydrology. 2008;8. 